\title{
Comparison between blood serum and salivary cortisol concentrations in horses using an adrenocorticotropic hormone challenge
}

\author{
M. PEETERS ${ }^{\star}$, J. SULON, J.-F. BECKERS, D. LEDOUX ${ }^{\dagger}$ and M. VANDENHEEDE \\ Faculté de Médecine Vétérinaire, Boulevard de Colonster, Liège; and 'Liège University Hospital, Belgium.
}

Keywords: horse; cortisol; ACTH challenge; saliva; stress

\section{Summary}

Reasons for performing study: In horses, serum cortisol concentration is considered to provide an indirect measurement of stress. However, it includes both free and bound fractions. The sampling method is also invasive and often stressful. This is not the case for salivary cortisol, which is collected using a more welfare-friendly method and represents a part of the free cortisol fraction, which is the biologically active form.

Objectives: To compare salivary and serum cortisol assays in horses, in a wide range of concentrations, using an adrenocorticotropic hormone (ACTH) stimulation test, in order to validate salivary cortisol for stress assessment in horse.

Methods: In 5 horses, blood samples were drawn using an i.v. catheter. Saliva samples were taken using swabs. Cortisol was assayed by radioimmunoassay. All data were treated with a regression method, which pools and analyses data from multiple subjects for linear analysis.

Results: Mean \pm s.d. cortisol concentrations measured at rest were $188.81 \pm 51.46 \mathrm{nmol} / \mathrm{l}$ in serum and $1.19 \pm 0.54 \mathrm{nmol} / \mathrm{l}$ in saliva. They started increasing immediately after ACTH injection and peaks were reached after $96 \pm 16.7 \mathrm{~min}$ in serum $(356.98 \pm 55.29 \mathrm{nmol} / \mathrm{l})$ and after $124 \pm 8.9 \mathrm{~min}$ in saliva $(21.79 \pm 7.74 \mathrm{nmol} / \mathrm{l}, \mathbf{P}<\mathbf{0 . 0 5})$. Discharge percentages were also different $(225 \%$ in serum and $2150 \%$ in saliva, $\mathbf{P}<\mathbf{0 . 0 5})$. Correlation between serum and salivary cortisol concentrations showed an adjusted $r^{2}=0.80 \quad(P<0.001)$. The strong link between serum and salivary cortisol concentrations was also estimated by a regression analysis.

Conclusions: The reliability of both RIAs and regression found between serum and salivary cortisol concentrations permits the validation of saliva-sampling as a noninvasive technique for cortisol level assessment in horses.

$\begin{array}{ll}\text { Abbreviations } & \\ \text { ACTH: } & \text { Adrenocorticotropic hormone } \\ \text { CBG: } & \text { Cortisol binding globulin } \\ \text { HPA axis: } & \text { Hypothalamic-pituitary-adrenal axis } \\ \text { MDL: } & \text { Minimum detection limits }\end{array}$

Introduction

Cortisol levels are used in man and in domestic and wild animal research. In main studies, serum cortisol concentration is considered to be an indirect measurement of stress (Mears and Brown 1997; Hennessy et al. 2001; Rushen et al. 2001; Möstl and Palme 2002; Krawczel et al. 2007). In horses, serum cortisol concentration is often used to assess stress induced by transport (Clark et al. 1993; Cavallone et al. 2002; Fazio et al. 2008), competition (Covalesky et al. 1992) and training (Alexander et al. 1991; Cayado et al. 2006), and stress associated with stereotypies (McGreevy and Nicol 1998). The increase in serum cortisol during acute stress is largely made up of free cortisol. When assessing stress, it is more useful and relevant to measure free cortisol than total cortisol in serum (Alexander and Irvine 1998; Hellhammer et al. 2009). Faecal cortisol metabolites are also used to assess long-term stress, but do not allow detection of minor and transient increases in plasma cortisol (Schmidt et al. 2009).

Salivary cortisol results from passive diffusion into the salivary glands and constantly provides information about free cortisol concentration. This concentration is, therefore, now used by more researchers as an index of serum free cortisol (Francis et al. 1987; Vincent and Michell 1992; Castro et al. 2000; Roy et al. 2001; Mormède etal. 2007; Wolf et al. 2008). Salivary cortisol concentration represents a part of free cortisol concentration. In horses, stress has already been assessed by salivary cortisol concentration during isolation (Harewood and McGowan 2005), weaning (Moons et al. 2005), transport (Schmidt et al. 2010a,b) or during new manipulations (Jongman et al. 2005). However, these researchers were not concerned with the relationship between serum and salivary cortisol concentrations in horses; they based their hypothesis on man or other species studies. The present study is a confirmation of these previous hypotheses.

In the saliva-sampling method, there is no risk of complications, unlike jugular catheterisation or venipuncture. Saliva-sampling is effectively a noninvasive method, painless and stress-free for horses that are used to be manipulated by man. This method is also easier than blood-sampling (Fell et al. 1985; Vincent and Michell 1992; Bushong etal. 2000; Negrao et al. 2004; Hellhammer et al. 2009). Nowadays, cortisol concentration can be assayed by using immunoassays. A direct radioimmunological method called

*Corresponding author email: marie.peeters@ulg.ac.be

[Paper received for publication 13.04.10; Accepted 06.07.10] 
radioimmunoassay (RIA) was used, based on a competition between unlabelled cortisol and cortisol radiolabelled with ${ }^{125}$ iodide, used in terms of sensitivity against the specific sites of an antibody previously described (Sulon et al. 1978). This technique has been widely validated in man (van Eck et al. 1996; Nicolson et al. 1997; Calixto et al. 2002) and equine studies (Hughes et al. 2006).

A positive correlation between equine serum and salivary cortisol concentrations has been established (Lebelt et al. 1996; Pell and McGreevy 1999; van der Kolk et al. 2001) or not (Elsaesser et al. 2001). Nevertheless, none of these studies provided a regression model to explain the relationship between serum and salivary cortisol concentrations. To establish this relationship, samples of saliva and blood are taken in parallel and in the present study adrenocorticotropic hormone (ACTH) administration, inducing a high cortisol secretion was used to extend the range of sample concentrations (Calixto et al. 2002; Bousquet-Mélou et al. 2006).

The first aim of the present study was to develop a sensitive and specific RIA to measure cortisol concentration precisely in serum and saliva. The secondary objectives were to study the kinetics of cortisol in both blood and saliva after an adrenal stimulation and to assess if their relationship could permit the use of saliva sampling instead of blood-sampling to assess hypothalamic-pituitary-adrenal (HPA) axis activity in horses. The ACTH challenge was chosen in order to standardise an adrenal stimulation.

\section{Materials and methods}

The Animal Care and Use Council of the University of Liège (Belgium) approved the use and treatment of animals in this study.

\section{Horses}

Five mature horses, 3 mares and 2 geldings, ranging in age from 9-17 years and weighing mean \pm s.d. $486 \pm 38 \mathrm{~kg}$, were used. All horses were healthy, not pregnant and accustomed to handling and sampling sessions. They were housed on straw in their usual stable (individual stalls), at the Faculty of Veterinary Medicine of Liège. Water was freely available in automatic drinking troughs. Horses were fed with pellets and hay. Throughout the study, they were always handled by the same experimenter.

\section{Experimental design and sampling}

A catheter (large bore i.v. catheter 14 gauge $\times 13.4 \mathrm{~cm})^{1}$ was placed in the jugular vein of each horse on Day 1. This placement was performed by an experienced veterinarian. The standardised dose, $1 \mu \mathrm{g} / \mathrm{kg}$ of ACTH (Synacthen tetracosactidum $0.25 \mathrm{mg} / 1 \mathrm{ml})^{2}$ was chosen according to the work of Bousquet-Mélou et al. (2006). ACTH was injected through the catheter, which was then flushed. During Day 1, 10 samples (5 saliva and 5 blood samples) were collected. First samplings were performed before catheter placement, and the others at 5, 10, 30 and 60 min after. During Day 2, 42 samples ( 21 blood and 21 saliva samples in parallel) were collected. First samplings were performed 30 and $15 \mathrm{~min}$ before ACTH injection and the following at 10, 20, 30, 40, 60, 80, 100, $120,140,160,180,200,220,240,280,320,260,400$ and $500 \mathrm{~min}$ after ACTH injection. At the end of Day 2, the catheter was removed.

\section{Blood and saliva sampling}

The first blood sample was collected by venipuncture before catheter placement. All other blood samples were drawn by i.v. catheter. Every blood sampling was followed by a cleaning injection of $1 \mathrm{ml}$ of physiological liquid containing heparin $(0.05 \%)$. Blood was collected in a clotting tube (Monovette) $)^{3}$ and immediately stored at $4^{\circ} \mathrm{C}$. Saliva was sampled using Salivette ${ }^{3}$. A swab on a metal clamp was maintained in the horse's mouth for 30-40 s, over and under the tongue and replaced in Salivettes and stored at $4^{\circ} \mathrm{C}$. At the end of each day, the Salivettes and clotting tubes were centrifuged $10 \mathrm{~min}$ at $1500 \mathrm{~g}$. Saliva and serum samples were stored at $-20^{\circ} \mathrm{C}$ until assayed (Garde and Hansen 2005).

\section{Development of salivary cortisol RIA}

In saliva, cortisol was assayed by a direct RIA. Minimum detection limits (MDL) were determined in each assay according to the protocol described by Skelley et al. (1973). The precision and reproducibility of the RIAs were calculated by the intra- and interassay coefficients of variation (CV). The buffer ( $\mathrm{pH} 7.0)$ used throughout the procedure contained $\mathrm{C}_{6} \mathrm{H}_{8} \mathrm{O}_{7} \cdot \mathrm{H}_{2} \mathrm{O}(0.206 \%)^{4}$, $\mathrm{Na}_{2} \mathrm{HPO}_{4} .2 \mathrm{H}_{2} \mathrm{O}(3.211 \%)^{5}, \mathrm{NaCl}(0.9 \%)^{6}$ and $\mathrm{NaN}_{3}(0.1 \%)^{6}$. The buffer was ready to use after the addition of bovine serum albumin (BSA $0.2 \%)^{7}$. Cortisol $^{8}$ was used as standard. Five $\mu \mathrm{g}$ of Cortisol3 CMO-histamine 9 in $10 \mu \mathrm{l}$ of phosphate buffer $(0.5 \mathrm{~mol} / \mathrm{l} \mathrm{pH} 7.5)$ were labelled with $2 \mathrm{mCi} \mathrm{Na}{ }^{125} \mathrm{I}^{10}$ by the usual chloramine-T method (Greenwood et al. 1963). The labelled solution was purified by high performance liquid chromatography (HPLC) on a C-18 reverse phase using an acetonitrile-water gradient. The primary antibody raised against cortisol-3-CMO-BSA was previously described by Sulon et al. (1978). The second antibody precipitation system consisted of a mixture of sheep anti-rabbit IgG $(0.83 \%, \mathrm{v} / \mathrm{v})$, normal rabbit serum $(0.17 \%, \mathrm{v} / \mathrm{v})$, polyethylene glycol $6000(4 \%)^{6}$, BSA $0.4 \%$ and microcrystalline cellulose $(0.05 \%)^{6}$.

At $300 \mu \mathrm{l}$ of buffer, $50 \mu \mathrm{l}$ of saliva were dispensed, in duplicate, in crystal polystyrene $(75 \times 12 \mathrm{~mm})$ tubes. $100 \mu$ l of diluted tracer solution (about 30,000 counts/min) and $100 \mu \mathrm{l}$ of antiserum (dilution $1 / 25,000$ ) were added. A standard curve, ranging from $0.22-55.17 \mathrm{nmol} / \mathrm{l}$ was prepared in buffer and used in parallel. All tubes were incubated overnight at room temperature. After that, $1 \mathrm{ml}$ of the second antibody precipitation system was added to all tubes and incubated $30 \mathrm{~min}$ at room temperature. After addition of $2 \mathrm{ml}$ of buffer, all tubes were centrifuged at $2890 \mathrm{~g}$ for $20 \mathrm{~min}$, in order to separate bound (pellet) and free (supernatant) ligands. The radioactivity of the dry pellet was counted using a gamma counter (126 Multigamma counter) ${ }^{11}$. Logit-log transformation was used to obtain a linear standard curve in order to estimate the salivary cortisol concentration (Banga-Mboko et al. 2003). As no chromatographic testing of the validity of the assay was done, we notice that cortisol concentration assayed is the immunoreactive cortisol concentration.

\section{Development of serum cortisol RIA}

In serum, dilutions were necessary before RIA. All the reagents and materials described above were also used for serum cortisol determination. A $1 \mathrm{mg} / \mathrm{ml}$ solution of 8-anilino-1-naphthalene sulphonic acid (ANS) ${ }^{12}$ prepared in buffer was used to avoid nonspecific binding of cortisol to serum proteins such as cortisol 
binding globulin (CBG) or albumin (Ronayne and Hynes 1990). Aliquots of $50 \mu 1$ of diluted (1/40) serum sample, were dispersed in polystyrene tubes in duplicate. A $300 \mu \mathrm{l}$ aliquot of tracer prepared in ANS solution $(30,000$ counts/min) and $100 \mu \mathrm{l}$ of primary antiserum were added. A calibration curve of cortisol, ranging from 8.6-2200 nmol/l, was obtained with a charcoal stripped cortisol free serum. The subsequent steps were as described for saliva samples.

\section{Statistics}

Continuous variables are reported as the mean \pm s.d. We used repeated measures ANOVA to analyse cortisol kinetic in serum and saliva. Variable normality was assessed using the Shapiro-Wilk test. Transformation was applied for variable normalisation when necessary. Since the observations available to assess the link between salivary and serum cortisol were data from multiple subjects, i.e. several measures were made per horse, independence of the observation could not be assumed. We therefore had to apply methods for pooling data from multiple subjects for linear analysis. This was done using the standardisation procedure for individual response curves described by Poon (1988). After this standardisation, the classical linear regression model was used to assess the association between salivary and serum cortisol and to propose a prediction model for salivary cortisol concentration.

Statistical analyses were performed using $\mathrm{R}$ version $2.8 .0^{13}$. A 2 -tailed $\mathrm{P}$ value $<0.05$ was considered statistically significant.

\section{Results}

Characterisation of cortisol RIAs

The MDL were 0.2 and $8 \mathrm{nmol} / \mathrm{l}$, respectively, in saliva and serum. In each case, 3 pools of saliva or serum containing low, moderate and high concentrations of cortisol were tested. Intra- and interassay $\mathrm{CV}$ determined at different ranges in the assays were $<5.55 \%(4.04 \pm 1.54 \%)$ and $<10.40 \%(9.13 \pm 1.33 \%)$ in saliva and, respectively, $<6.53 \%(4.32 \pm 1.92 \%)$ and $<11.27 \%(8.22 \pm$ $2.69 \%)$ in serum. Parallelism was assessed by serial dilutions (1:1, $1: 2,1: 4,1: 8$ and $1: 16$ ) of saliva (CV $5.91 \%$ ) or serum (CV 4.43\%) samples, selected with a high cortisol concentration.

\section{Physiological validation of salivary and serum cortisol RIAs}

Cortisol concentrations at rest: Saliva was collected with the Salivette without any problem. Horses accepted easily the metal clamp in their mouth. No increase in cortisol concentration appeared after saliva sampling (neither in serum nor saliva). Horses stayed calm and learned quickly (after 2 trials) to accept the swab. Horses did not need any special restraint to sample saliva, which was performed in the horse's stable. At $08.55 \mathrm{~h}$ on Day 1, before catheter placement, serum cortisol concentration varied from $137.84-256.92 \mathrm{nmol} / \mathrm{l}(188.81 \pm 51.46 \mathrm{nmol} / \mathrm{l})$. At the same time, salivary cortisol concentration varied from $0.58-1.77 \mathrm{nmol} / \mathrm{l}$ $(1.19 \pm 0.54 \mathrm{nmol} / \mathrm{l})$.

During i.v. catheter placement: At $09.00 \mathrm{~h}$ on Day 1, the i.v. catheter was placed and serum cortisol concentrations showed no significant variation during the following hour (repeated measures ANOVA). At $10.00 \mathrm{~h}$, serum cortisol concentrations varied from
$146-222 \mathrm{nmol} / \mathrm{l}(182.98 \pm 31.49 \mathrm{nmol} / \mathrm{l})$. At the same time, salivary cortisol concentrations varied from $0.59-2.21 \mathrm{nmol} / \mathrm{l}$ $(1.27 \pm 0.60 \mathrm{nmol} / \mathrm{l})$, values that are also not significantly different from those measured before the catheter placement (repeated measures ANOVA).

During an ACTH stimulation test: Figure 1 illustrates both the serum and the saliva cortisol responses, after ACTH administration. Thirty minutes earlier, the serum cortisol concentration (baseline) varied from $125-224 \mathrm{nmol} / \mathrm{l}(148.14 \pm 42.69 \mathrm{nmol} / \mathrm{l})$. Ten minutes after ACTH administration, the cortisol concentration was higher than baseline (repeated measures ANOVA, $\mathrm{P}<0.01$ ). In the mean for the 5 horses, the peak was reached in serum after $96 \pm$ $16.7 \mathrm{~min}$; this peak was $356.98 \pm 55.29 \mathrm{nmol} / \mathrm{l}$. Thereafter, serum cortisol concentration decreased regularly to return to baseline at $280 \mathrm{~min}$ after ACTH injection (repeated measures ANOVA, $\mathrm{P}<0.05$ ). We noticed that at $400 \mathrm{~min}$ after ACTH administration, the serum cortisol concentration dropped below the baseline (repeated measures ANOVA, $\mathrm{P}<0.01$ ), to reach a concentration of $62.39 \pm 16.14 \mathrm{nmol} / \mathrm{l}$, at $500 \mathrm{~min}$ after ACTH injection. Thirty minutes before stimulation, salivary cortisol concentrations (baseline) varied from $0.46-3.14 \mathrm{nmol} / \mathrm{l}(1.23 \pm 1.08 \mathrm{nmol} / \mathrm{l}) . \mathrm{In}$ saliva, cortisol concentration was significantly higher than baseline after $30 \mathrm{~min}$ (repeated measures ANOVA, $\mathrm{P}<0.05$ ) and after $40 \mathrm{~min}$ $(\mathrm{P}<0.01), 20-30$ min later than in blood. The mean peak was $21.79 \pm 7.74 \mathrm{nmol} / \mathrm{l}$, appearing about $124 \pm 8.9 \mathrm{~min}$ after ACTH administration. The salivary cortisol concentration came back to baseline after $180 \mathrm{~min}(\mathrm{P}>0.05), 100 \mathrm{~min}$ earlier than in blood (Fig 1).

On average, the peak was reached in serum after $96 \pm 16.7 \mathrm{~min}$ and in saliva after $124 \pm 8.9 \mathrm{~min}$. Times needed to reach the peak are significantly different (paired Student $t$ test, $\mathrm{P}<0.05$ ). Times to come back to baseline were also different: about $280 \mathrm{~min}$ in serum and $180 \mathrm{~min}$ in saliva.

The mean percentage of discharge in serum was $225 \%$ $(148.14-358.08 \mathrm{nmol} / \mathrm{l})$, while it was $2150 \%$ in saliva $(1.23-21.79 \mathrm{nmol} / \mathrm{l})$ (significantly different, paired Student $t$ test, $\mathrm{P}<0.05)$.

\section{Regression analysis}

During the study, 127 sera and 127 salivas were sampled in parallel on the 5 horses. These results show a time lag between serum cortisol and saliva cortisol variation. As expected, saliva cortisol increasing appears 20-30 min later than in serum. Because this time lag is changeable, depending on intensity and duration of stressor, statistical analysis was based on values gathered simultaneously. There was a strong association between salivary and serum cortisol as shown by a Pearson correlation coefficient of 0.90 and an adjusted $\mathrm{r}^{2}$ of $0.80(\mathrm{P}<0.0001)$. This means that $80 \%$ of the salivary cortisol concentration variability could be explained by the serum cortisol concentration and reciprocally. The obtained classical linear regression (Fig 2) model is shown below:

$$
\text { Cortisol }_{\text {serum }}=159+56.7 \log _{\mathrm{e}} \text { cortisol }_{\text {saliva }}
$$

\section{Discussion}

In previous studies in man (Walker et al. 1978; Lac 2001) and in dogs (Beerda et al. 1996), the RIA method was found to be sensitive and reproducible for cortisol concentration determination 


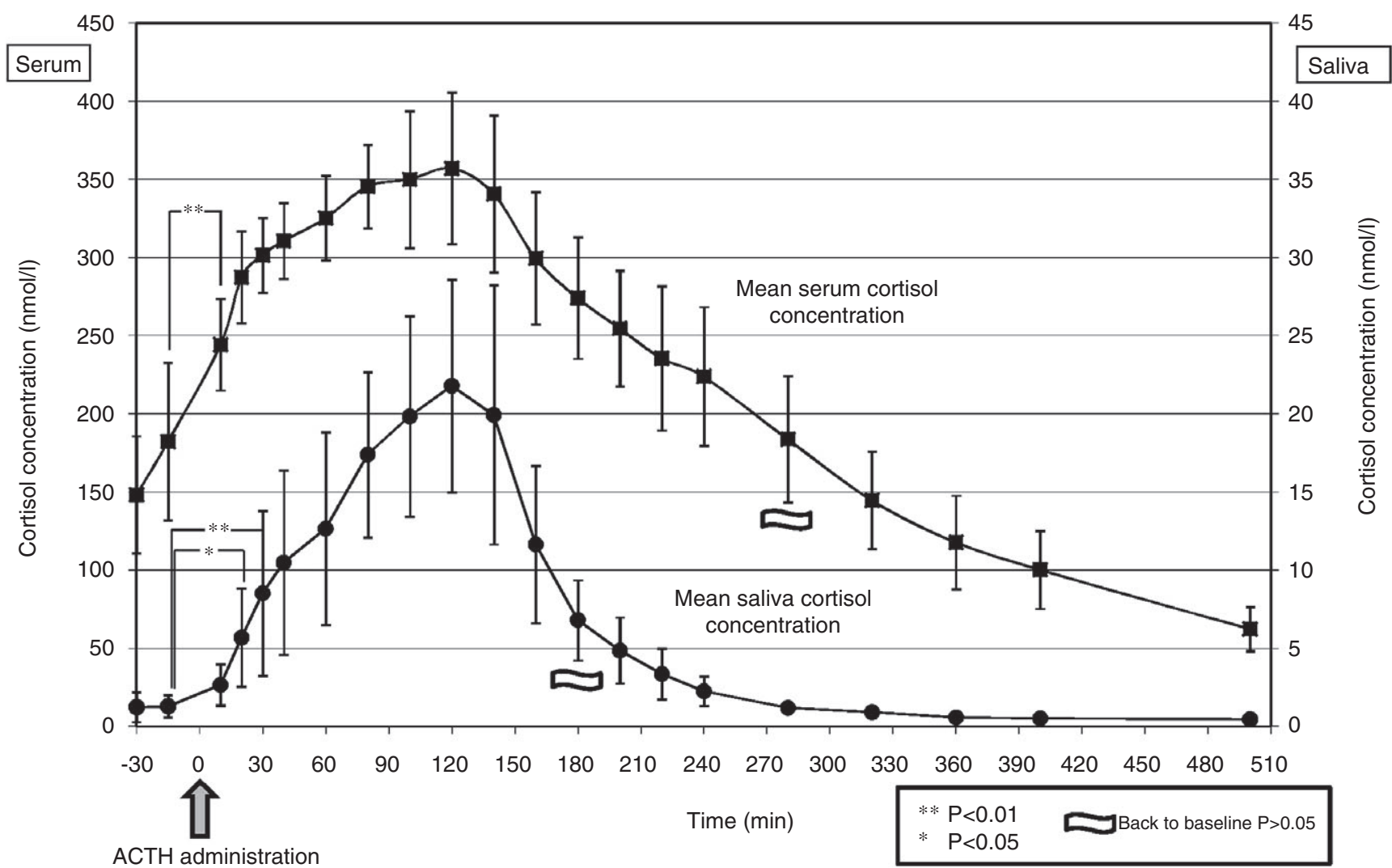

Fig 1: Means of total serum cortisol concentration and saliva cortisol concentration during an ACTH challenge for the 5 horses.

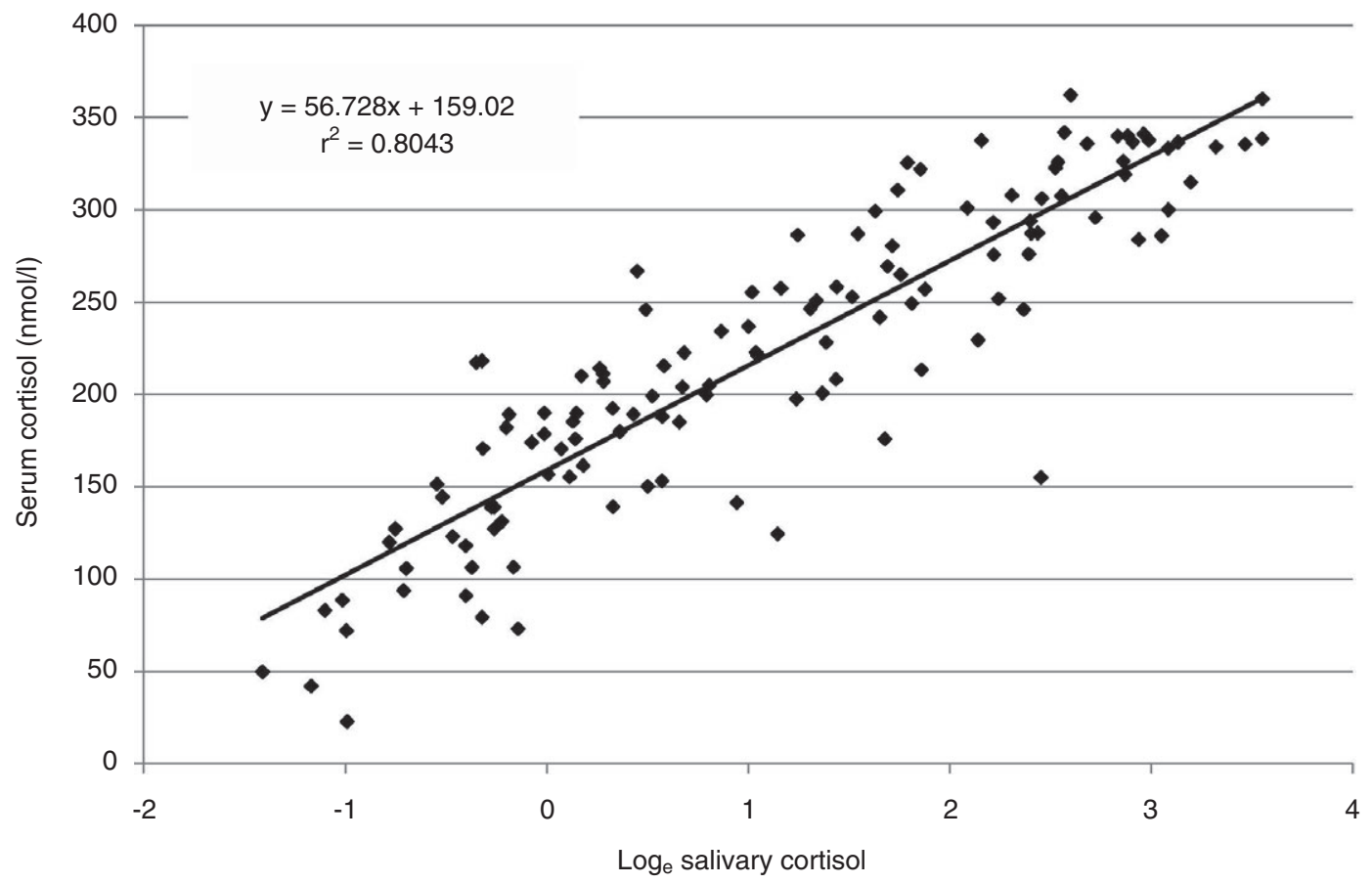

Fig 2: Linear regression found between total serum cortisol concentration and saliva cortisol concentration, for the 5 horses, during an ACTH challenge.

in both serum and saliva. In horses, there are few studies about the validation of salivary cortisol as an indicator of HPA activity. Saliva and blood samples on a small range of value were collected (Pell and McGreevy 1999; Creighton et al. 2004). If an ACTH stimulation test was used, the authors collected insufficient samples to find a significant regression (van der Kolk et al. 2001). The i.v. injection of ACTH to horses stimulates the HPA axis and induces a wide range of cortisol values in serum and saliva. This technique 
was used to compare salivary and serum cortisol rises, around a standardised physiological stress and the physiological response of cortisol after ACTH injection validated this RIA study from low $(0.24 \mathrm{nmol} / \mathrm{l}$ in saliva and $45 \mathrm{nmol} / 1$ in serum) to high values of cortisol $(35 \mathrm{nmol} / \mathrm{l}$ in saliva and $420 \mathrm{nmol} / 1$ in serum). In the present study, RIA was a sensitive and specific method to measure cortisol concentration in horses precisely, in 2 very different fluids, serum and saliva, as previously validated by Hughes et al. (2006) in saliva.

Cortisol concentrations obtained during resting time are in agreement with results from other studies, for both serum (Alexander et al. 1991; Anderson et al. 1999; Cavallone et al. 2002) and saliva (Pell and McGreevy 1999; van der Kolk et al. 2001) concentrations. Cortisol concentrations during venous catheter placement increased, but did not differ significantly from baseline, in both serum and saliva. This means that catheter placement should not involve as high a stress to horses as transport (Fazio et al. 2008; Schmidt et al. 2010b) or competition (Cayado et al. 2006).

In serum, the cortisol response to ACTH challenge was in accordance with previous studies in horses, with the same timing and peak amplitude (van der Kolk et al. 2001; Bousquet-Mélou et al. 2006). Bousquet-Mélou et al. (2006) obtained, for the same ACTH quantity, the same timing and amplitude for serum cortisol concentrations. Van der Kolk et al. (2001) also used an ACTH challenge to compare serum and salivary cortisol concentrations. They took 3 saliva samples and 3 blood samples after ACTH administration (after 2, 4 and $6 \mathrm{~h}$ ). Their peak on the first sample $(\mathrm{ACTH}+2 \mathrm{~h})$ and concentration correspond to our peak (20.40 \pm 5.50 and $413.0 \pm 91.6 \mathrm{nmol} / \mathrm{l}$ in saliva and serum).

Many studies have found a significant positive correlation between serum and salivary cortisol, for example in man (DemeyPonsart et al. 1986), guinea pigs (Fenske 1996) and cattle (Negrao et al. 2004). In a previous study (Peeters et al. 2008), a positive correlation of $0.55(\mathrm{P}<0.05)$ was found between mean cortisol concentrations (5 samples/day) in serum and saliva in horses. Some previous studies found no such correlation (Pell and McGreevy 1999) while others found a correlation, but only with a few samples (Lebelt et al. 1996). In the present study, the saliva/ serum correlation was positive and significant $\left(\mathrm{r}^{2}=0.90 ; \mathrm{P}<0.001\right.$; $\mathrm{n}=127$ ) and there was a strong association between salivary and total serum cortisol concentrations as shown by an adjusted $\mathrm{r}^{2}$ of $0.80 \quad(\mathrm{P}<0.001)$, meaning that $80 \%$ of the salivary cortisol concentration variability could be explained by the total serum cortisol concentration and reciprocally. The regression relationship between these concentrations was therefore calculated and the relation can be more precisely illustrated with the following formula: cortisol $_{\text {serum }}=159+56.7 \log _{\mathrm{e}}$ cortisol $_{\text {saliva. }}$. The total serum cortisol concentration can be deduced from this formula, for salivary cortisol concentrations $0.24-34.83 \mathrm{nmol} / \mathrm{l}$. Bousquet-Mélou et al. (2006) and Dorin et al. (2009) found that free cortisol in serum is not proportional to total serum cortisol. This explains the nonlinearity of the relationship between total serum and salivary cortisol concentrations found in the present study. This nonlinearity might be due to the variable saturation state of $\mathrm{CBG}$ and albumin. The maximal binding capacity of $\mathrm{CBG}$ is reached during an ACTH test (Bousquet-Mélou et al. 2006). In stress research, a biologically active cortisol form gives us more information about HPA axis activity. Studies comparing free serum cortisol to salivary cortisol in horses may lead to a linear relation as found for man (Arafah et al. 2007). Under stress conditions, the CBG becomes saturated, leading to an increase in free cortisol. This fact explains why the relative increase of cortisol in saliva is higher than in serum (about 10 times more). This high increase in salivary cortisol has already been found in previous studies on dogs (Vincent and Michell 1992) and horses (van der Kolk et al. 2001).

Cortisol concentrations came back to baseline faster in saliva than in serum (100 min faster). In horses, saliva sampling should therefore be preferred to blood sampling for stress level assessment, as Hellhammer et al. (2009) indicated for human individuals. In human research, le Roux et al. (2003) also found that free cortisol index is a better indication of HPA axis activity than serum total cortisol, all the more in acute stress situation, when CBG fall dramatically (le Roux et al. 2003). However, the time lag varies between serum and saliva cortisol. The regression found does not mean that saliva cortisol concentration can be used to calculate serum cortisol concentration but saliva cortisol concentration can be used to detect HPA axis activity as with serum cortisol. Moreover, salivary cortisol concentration seems to be more expressive and more specific to assess an increase of the HPA axis activity.

In others species, authors have already postulated that saliva sampling is a good alternative to blood sampling for free cortisol measurements. They explain this by various factors endorsed in the present study: 1) saliva is easy and noninvasive to collect;2) in saliva, there is only free cortisol, so no separation manipulation is needed; 3) salivary cortisol concentration is independent of flow rate (Riad-Fahmy et al. 1982); according to the present results, also 4) cortisol in saliva has a higher increase when stress occurs (10 times more than in serum) and 5) salivary cortisol concentrations come back to baseline faster than serum concentrations; these points permit a better determination of stress occurring. In the present study a regression formula was also calculated to compare results from studies that used serum cortisol concentration to assess HPA axis activity.

In conclusion, as expected, saliva sampling and saliva RIAs are valid and noninvasive techniques for cortisol measurement in horses. The study agrees with Lebelt et al. (1996) that saliva may become the body fluid of choice for monitoring stress. The kinetics of salivary cortisol concentrations around a standardised stress are further revealed and this information is useful to determine good timing for saliva sampling in future stress and/or welfare studies in horses, as reported by Peeters et al. (2010).

\section{Acknowledgements}

The authors thank Julie Désirant for assistance with the English translation. We thank the Reproduction Physiology department of the University of Liège (Belgium) for its cordial welcome to its laboratory. We also thank the Physiology department of the Veterinary faculty for practical help. The work was supported by grants from the FRIA-FNRS. No conflicts of interest have been declared.

\section{Manufacturers' addresses}

${ }^{1}$ Jorvet, Loveland, Colorado, USA

${ }^{2}$ Novartis, Vilvoorde, Belgium.

${ }^{3}$ Sarstedt, Nümbrecht, Germany.

${ }^{4}$ Fluka, Bornem, Belgium.

${ }^{5} \mathrm{BDH}$, Leuven, Belgium.

${ }^{6}$ Merck, Leuven, Belgium. 
${ }^{7}$ INC Biochemicals, Aurora, Ohio, USA

${ }^{8}$ Sigma, St Louis, Missouri, USA.

${ }^{9}$ Research Plus, Bayonne, New Jersey, USA.

${ }^{10}$ PerkinElmer, Zaventem, Belgium.

${ }^{11}$ LKB Wallac, Turku, Finland.

${ }^{12}$ Eastman Kodak Co., Rochester, New York, USA.

${ }^{13} \mathrm{http}: / /$ www.R-project.org

\section{References}

Alexander, S.L. and Irvine, C.H. (1998) The effect of social stress on adrenal axis activity in horses: The importance of monitoring corticosteroid-binding globulin capacity. J. Endocrinol. 157, 425-432.

Alexander, S.L., Irvine, C.H., Ellis, M.J. and Donald, R.A. (1991) The effect of acute exercise on the secretion of corticotropin- releasing factor, arginine vasopressin, and adrenocorticotropin as measured in pituitary venous blood from the horse. Endocrinol. 128, 65-72.

Anderson, M.K., Friend, T.H., Evans, J.W. and Bushong, D.M. (1999) Behavioral assessment of horses in therapeutic riding programs. Appl. anim. behav. Sci. $\mathbf{6 3}$, 11-24.

Arafah, B.M., Nishiyama, F.J., Tlaygeh, H. and Hejal, R. (2007) Measurement of salivary cortisol concentration in the assessment of adrenal function in critically ill subjects: A surrogate marker of the circulating free cortisol. J. clin. Endocrinol. Metab. 92, 2965-2971.

Banga-Mboko, H., Sulon, J., Closset, J., Remy, B., Youssao, I., De Sousa, N.M., El Amiri, B., Sangild, P.T., Maes, D. and Beckers, J.F. (2003) An improved radioimmunoassay for measurement of pepsinogen in porcine blood samples. Vet. J. 165, 288-295.

Beerda, B., Schilder, M.B.H., Janssen, N.S.C.R.M. and Mol, J.A. (1996) The use of saliva cortisol, urinary cortisol, and catecholamine measurements for a noninvasive assessment of stress responses in dogs. Horm. Behav. 30, 272-279.

Bousquet-Mélou, A., Formentini, E., Picard-Hagen, N., Delage, L., Laroute, V. and Toutain, P.-L. (2006) The adrenocorticotropin stimulation test: Contribution of a physiologically based model developed in horse for its interpretation in different pathophysiological situations encountered in man. Endocrinol. 147, 4281-4291.

Bushong, D.M., Friend, T.H. and Knabe, D.A. (2000) Salivary and plasma cortisol response to adrenocorticotropin administration in pigs. Lab. Anim. 34, 171-181.

Calixto, C., Martinez, F.E., Jorge, S.M., Moreira, A.C. and Martinelli, C.E. (2002) Correlation between plasma and salivary cortisol levels in preterm infants. $J$. Pediatr. 140, 116-118.

Castro, M., Elias, P.C.L., Martinelli, C.E.J., Antonini, S.R.R., Santiago, L. and Moreira, A.C. (2000) Salivary cortisol as a tool for physiological studies and diagnistic strategies. Braz. J. med. biol. Res. 33, 1171-1175.

Cavallone, E., Giancamillo, M.D., Secchiero, B., Belloli, A., Pravettoni, D. and Rimoldi, E.M. (2002) Variations of serum cortisol in Argentine horses subjected to ship transport and adaptation stress. J. equine vet. Sci. 22, 541-545.

Cayado, P., Munoz-Escassi, B., Dominguez, C., Manley, W., Olabarri, B., Sanchez de la Muela, M., Castejon, F., Maranon, G. and Vara, E. (2006) Hormone response to training and competition in athletic horses. Equine vet. J., Suppl. 36, 274-278.

Clark, D.K., Friend, T.H. and Dellmeier, G. (1993) The effect of orientation during trailer transport on heart rate, cortisol and balance in horses. Appl. anim. behav. Sci. 38, 179-189.

Covalesky, M.E., Russoniello, C.R. and Malinowski, K. (1992) Effects of showjumping performance stress on plasma cortisol and lactate concentrations and heart rate and behavior in horses. J. equine vet. Sci. 12, 244-251.

Creighton, E., Hughes, T. and Coleman, R. (2004) Validation of salivary cortisol as an indicator of stress in horses (Equus caballus). In: Proceedings of the 38th International Congress of the ISAE, Col. University of Helsinki, Finland. p 186.

Demey-Ponsart, E., Sulon, J., Sodoyer, J.C., Bourque, J., Gaspard, U.J. and van Cauwenberge, H. (1986) Stéroïdes salivaires et hormones plasmiques libres chez la femme. J. Gynécol. Obstet. Biol. Reprod. 15, 615-619.

Dorin, R.I., Pai, H.K., Ho, J.T., Lewis, J.G., Torpy, D.J., Urban Iii, F.K. and Qualls, C.R. (2009) Validation of a simple method of estimating plasma free cortisol: Role of cortisol binding to albumin. Clin. Biochem. 42, 64-71.

Elsaesser, F., Klobasa, F. and Ellendorff, F. (2001) Evaluation of salivary cortisol determination and of cortisol responses to ACTH as markers of the training status/fitness of warmblood sports horses. Dtsch. Tierarztl. Wochenschr. 108, 31-36.
Fazio, E., Medica, P., Aronica, V., Grasso, L. and Ferlazzo, A. (2008) Circulating beta-endorphin, adrenocorticotrophic hormone and cortisol levels of stallions before and after short road transport: Stress effect of different distances. Acta vet. Scand. 50, 6.

Fell, L., Shutt, D. and Bentley, C. (1985) Development of a salivary cortisol method for detecting changes in plasma 'free' cortisol arising from acute stress in sheep. Aust. vet. J. 62, 403-406.

Fenske, M. (1996) Saliva cortisol and testosterone in the guinea pig: measures for the endocrine function of adrenals and testes? Steroids 61, 647-650.

Francis, S.J., Walker, R.F., Riad-Fahmy, D., Hughes, D., Murphy, J.F. and Gray, O.P. (1987) Assessment of adrenocortical activity in term newborn infants using salivary cortisol determinations. J. Pediatr. 111, 129-133.

Garde, A.H. and Hansen, A.M. (2005) Long-term stability of salivary cortisol. Scand. J. clin. Lab. Invest. $\mathbf{6 5}, 433-436$.

Greenwood, F.C., Hunter, W.M. and Glover, J.S. (1963) The preparation of 131-Ilabelled human growth hormone of high specific radioactivity. Biochem. J. 89, 14-123.

Harewood, E.J. and McGowan, C.M. (2005) Behavioral and physiological responses to stabling in naive horses. J. equine vet. Sci. 25, 164-170.

Hellhammer, D.H., Wüst, S. and Kudielka, B.M. (2009) Salivary cortisol as a biomarker in stress research. Psychoneuroendocrinol. 34, 163-171.

Hennessy, M.B., Voith, V.L., Mazzei, S.J., Buttram, J., Miller, D.D. and Linden, F. (2001) Behavior and cortisol levels of dogs in a public animal shelter, and an exploration of the ability of these measures to predict problem behavior after adoption. Appl. anim. behav. Sci. 73, 217-233.

Hughes, T., Creighton, E. and Coleman, R. (2006) Validation of salivary cortisol as an indicator of HPA activity in horses. Proceedings of the 41st International Congres of the ISAE, Merida, Mexico. p 157.

Jongman, E.C., Bidstrup, I. and Hemsworth, P.H. (2005) Behavioural and physiological measures of welfare of pregnant mares fitted with a novel urine collection device. Appl. anim. behav. Sci. 93, 147-163.

Krawczel, P.D., Friend, T.H., Caldwell, D.J., Archer, G. and Ameiss, K. (2007) Effects of continuous versus intermittent transport on plasma constituents and antibody response of lambs. J. anim. Sci. 85, 468-476.

Lac, G. (2001) Saliva assays in clinical and research biology. Pathol. Biol. 49, 660667.

le Roux, C.W., Chapman, G.A., Kong, W.M., Dhillo, W.S., Jones, J. and AlaghbandZadeh, J. (2003) Free cortisol index is better than serum total cortisol in determining hypothalamic-pituitary-adrenal status in patients undergoing surgery. J. clin. Endocrinol. Metab. 88, 2045-2048.

Lebelt, D., Schonreiter, S. and Zanella, A.J. (1996) Salivary cortisol in stallions: The relationship with plasma levels, daytime profile and changes in response to semen collection. Pferdeheilkunde 12, 411-414.

McGreevy, P. and Nicol, C. (1998) Physiological and behavioral consequences associated with short-term prevention of crib-biting in horses. Physiol. Behav. $\mathbf{6 5}$, $15-23$.

Mears, C.J. and Brown, F.A. (1997) Cortisol and $\beta$-endorphin responses to physical and physiological stressors in lambs. Can. J. anim. Sci. 77, 689-694.

Moons, C.P.H., Laughlin, K. and Zanella, A.J. (2005) Effects of short-term maternal separations on weaning stress in foals. Appl. anim. behav. Sci. 91, 321-335.

Mormède, P., Andanson, S., Aupérin, B., Beerda, B., Guémené, D., Malmkvist, J., Manteca, X., Manteuffel, G., Prunet, P., van Reenen, C.G., Richard, S. and Veissier, I. (2007) Exploration of the hypothalamic-pituitary-adrenal function as a tool to evaluate animal welfare. Physiol. Behav. 92, 317-339.

Möstl, E. and Palme, R. (2002) Hormones as indicators of stress. Domest. Anim. Endocrinol. 23, 67-74.

Negrao, J.A., Porcionato, M.A., de Passille, A.M. and Rushen, J. (2004) Cortisol in saliva and plasma of cattle after ACTH administration and milking. J. Dairy Sci. 87, 1713-1718.

Nicolson, N., Storms, C., Ponds, R. and Sulon, J. (1997) Salivary cortisol levels and stress reactivity in human aging. J. Gerontol. A Biol. Sci. Med. Sci. 52, M68-M75.

Peeters, M., Péters, F., Sulon, J., Sandersen, C., Poncin, P., Serteyn, D. and Vandenheede, M. (2008) Behavioural and physiological assessment of stress level in hospitalised horses: Correlation between parameters. In: The 42nd Congress of the International Society for Applied Ethology, Eds: L. Boyle, N. O'Connell and A. Hanlon, UCD in Dublin, Dublin. p 153.

Peeters, M., Sulon, J., Serteyn, D. and Vandenheede, M. (2010) Assessment of stress level in horses during competition using salivary cortisol: preliminary studies. J. Vet. Behav. Clin. Appl. Res. 5, 216. 
Pell, S.M. and McGreevy, P.D. (1999) A study of cortisol and beta-endorphin levels in stereotypic and normal Thoroughbreds. Appl. anim. behav. Sci. 64, 81-90.

Poon, C.-S. (1988) Analysis of linear and mildly nonlinear relationships using pooled subject data. J. appl. Physiol. 64, 854-859.

Riad-Fahmy, D., Read, G.F., Walker, R.F. and Griffiths, K. (1982) Steroids in saliva for assessing endocrine function. Endocr. Rev. 3, 367-395.

Ronayne, E. and Hynes, N. (1990) Measurement of plasma progesterone concentrations by extraction and non-extraction radioimmunoassays. Irish $J$. Agric. Res. 29, 109-115.

Roy, M.P., Kirschbaum, C. and Steptoe, A. (2001) Psychological, cardiovascular, and metabolic correlates of individual differences in cortisol stress recovery in young men. Psychoneuroendocrinol. 26, 375-391.

Rushen, J., Munksgaard, L., Marnet, P.G. and DePassillé, A.M. (2001) Human contact and the effects of acute stress on cows at milking. Appl. anim. behav. Sci. 73, 1-14

Schmidt, A., Mostl, E., Aurich, J., Neuhauser, S. and Aurich, C. (2009) Comparison of cortisol and cortisone levels in blood plasma and saliva and cortisol metabolite concentrations in faeces for stress analysis in horses. In: 5th International Equitation Science Conference Eds: P. McGreevy, A. Warren-Smith and C. Oddie, Sydney. p 53.

Schmidt, A., Biau, S., Möstl, E., Becker-Birck, M., Morillon, B., Aurich, J., Faure J.M. and Aurich, C. (2010a) Changes in cortisol release and heart rate variability in sport horses during long-distance road transport. Domest. Anim. Endocrinol. 38, 179-189.

Schmidt, A., Möstl, E., Wehnert, C., Aurich, J., Müller, J. and Aurich, C. (2010b) Cortisol release and heart rate variability in horses during road transport. Horm. Behav. 57, 209-215.
Skelley, D.S., Brown, L.P. and Besch, P.K. (1973) Radioimmunoassay. Clin. Chem. 19, 146-186.

Sulon, J., Demey-Ponsart, L., Beauduin, P. and Sodoyez, J.C. (1978) Radioimmunoassay of corticosterone, cortisol and cortisone: their application to human cord and maternal plasma. J. Steroid Biochem. 9, 671-676.

Van der Kolk, J.H., Nachreiner, R.F., Schott, H.C., Refsal, K.R. and Zanella, A.J. (2001) Salivary and plasma concentration of cortisol in normal horses and horses with Cushing's disease. Equine vet. J. 33, 211-213.

Van Eck, M., Berkhof, H., Nicolson, N. and Sulon, J. (1996) The effects of perceived stress, traits, mood states, and stressful daily events on salivary cortisol. Psychosom. Med. 58, 447-458

Vincent, I.C. and Michell, A.R. (1992) Comparison of cortisol concentrations in saliva and plasma of dog. Res. vet. Sci. 53, 342-345.

Walker, R.F., Riad-Fahmy, D. and Read, G.F. (1978) Adrenal status assessed by direct radioimmunoassay of cortisol in whole saliva or parotid saliva. Clin. Chem. $\mathbf{2 4}$ $1460-1463$.

Wolf, J.M., Nicholls, E. and Chen, E. (2008) Chronic stress, salivary cortisol, and [alpha]-amylase in children with asthma and healthy children. Biol. Psychol. 78, $20-28$

Author contributions M.P. and M.V. conducted the study, from the conception and design to the acquisition, analysis and interpretation of data; J.S. and J.-F.B. collaborated for cortisol radioimmunoassay; D.L. gave valuable help with statistical analysis; M.P. and M.V. wrote the article and all the other authors revised it and approved the final version to be submitted.

\title{
The Equine Distal Limb
}

\section{J.-M. Denoix}

EVJ price: $£ 121.50$ plus p\&p

Manson Publishing, 400 pages, Hardback

Jean-Marie Denoix is the world's leading equine musculoskeletal system anatomist and has become one of the foremost equine diagnostic ultrasonographers. There is therefore nobody better to compile a reference atlas of the clinical anatomy of the foot, pastern and fetlock, correlated with images obtained by radiography, diagnostic ultrasonography and magnetic resonance imaging.

This book provides a unique contribution and will be an invaluable reference text. The image quality is extraordinarily high and the multiple views of each area of the distal limb provide an extremely detailed evaluation. Each part opens with a characteristically superb anatomical drawing by the author. Each spread of pages deals with a single dissection viewed by means of colour photographs, labelled black and white equivalents, plus x-rays, ultrasound and MRI scans as required. The book is designed for maximum clarity using a generous page size. The atlas will be essential for anybody involved in detailed anatomical study, complex lameness evaluation or advanced imaging techniques.

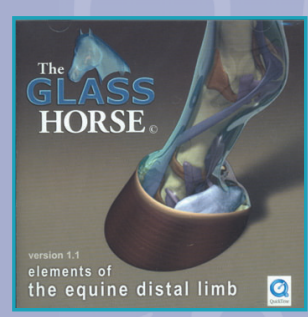

\section{The Glass Horse Equine Distal Limb CD}

\author{
Dr. J. Moore \& Dr. A. Parks
}

EVJ price: $\mathbf{f 6 0}$ plus VAT and $p \& p$

\section{... Presenting the first 3D interactive examination of the distal limb. Finally, a way to understand the equine distal limb! Includes text, audio and photo-realistic 3D animations \\ Available in Windows or Mac format, please specify when ordering.}

BEVA members now receive an extra 10\% off website prices - just email your order to Emma@evj.co.uk to receive the extra discount!

EVJ Bookshop, Mulberry House, 31 Market Street, Fordham, Ely, Cambs. CB7 5LQ, UK Tel: $01638720068 \uparrow$ Fax: $01638721868 \uparrow$ Email: emma@evj.co.uk $\downarrow$ www.evj.co.uk 